FOLIA HISTORICA CRACOVIENSIA, 22: 2016, s. 173-188

DOI: http://dx.doi.org/10.15633/fhc. 2078

Aneta Kramiszewska

Katolicki Uniwersytet Lubelski Jana PawŁa II

\title{
„Weź swój krzyż i idź za Jezusem...” \\ Wizerunek człowieka niosącego krzyż jako alegoria życia zakonnego
}

„Kto nie bierze swojego krzyża, a idzie za mną, nie jest mnie godzien” (Mt 10, 38) z mocą nauczał Jezus. Krzyż ten należy brać na barki każdego dnia (Łk 9, 23), nie ustając, ponieważ nie ma innego sposobu, aby zadość uczynić wezwaniu Zbawiciela. „Kto chce pójść za mną, niech się zaprze samego siebie, niech weźmie swój krzyż i niech mnie naśladuje" (Mk 8, 34, par. Mt 16, 24) - tak pouczał On nie tylko wybranych uczniów, „przywołał do siebie tłum”, aby ogłosić to wszystkim ludziom. Wierni temu przesłaniu komentatorzy tekstów biblijnych, egzegeci, teologowie i mistycy przez kolejne wieki rozwijali, pogłębiali, komentowali i objaśniali ideę naśladowania Chrystusa, posługując się chętnie także biblijną metaforą „wzięcia krzyża na swoje ramiona”. Niniejszy artykuł jest przyczynkiem do badań nad ideą naśladowania Chrystusa, wyrażoną w ikonografii chrześcijańskiej za pomocą wyżej wskazanej obrazowej metafory dźwigania krzyża wespół z Chrystusem.

Sens tej metafory komplementarnie słowem i obrazem doskonale objaśnia Speculum humanae salvationis, w którym do tekstu zasadniczego dołączono septem stationibus passionis Jesu Christi, czyli stacje Męki Pańskiej według godzin kanonicznych prezentowane ${ }^{1}$. Wprowadzające rozważanie na temat tego, jak uniknąć kary potępienia, a na chwałę Bożą zasłużyć, daje za przykład człowieka, który pozostając w swojej izdebce, prosi Boga nieustannie, aby objawił

\footnotetext{
1 Rysunki bądź miniatury o analogicznej tematyce pojawiają się w różnych kodeksach Speculum, tu odwołujemy się do egzemplarza powstałego w pierwszej połowie xIV wieku, przechowywanego w Rzymie, wyróżniającego się umieszczeniem na każdej karcie dodatkowej miniatury z cyklu ilustrującego żywot św. Franciszka z Asyżu (Biblioteca dell'Accademia Nazionale dei Lincei e Corsiniana). Zob. Ch. Frugoni, F. Manzari, Immagini di san Francesco in uno Speculum humanae salvationis del Trecento, Padova 2006, passim.
} 
mu swoją wolę. Widzi wówczas Chrystusa z ogromnym krzyżem na barkach, mówiącego: „Nie mogłeś sprawić mi większej przyjemności niż to, że pragniesz ten ciężki krzyż nieść”. W odpowiedzi człowiek prosi: „Błagam, mój najsłodszy Panie, naucz mnie, jakimi sposobami mógłbym Twój najświętszy krzyż z Tobą dźwigać”. Wówczas padają ważkie słowa Chrystusowego pouczenia: „W sercu przez współczucie, ustami - przez nieustające żarliwe wyznawanie pobożnej wdzięczności, uszami - słuchając upomnień o karach za złe życie, w ciele - przez umartwienia dotkliwe swojego ciała" ${ }^{2}$. Tekstowi towarzyszy ilustracyjne przedstawienie na jednej z miniatur, ukazujące ogromną postać niemal nagiego Chrystusa, $\mathrm{z}$ widocznymi ranami i krzyżem na ramieniu, rozmawiającego $\mathrm{z}$ mężczyzną wychylającym się z okna dwukondygnacyjnego budynku (il. 1) ${ }^{3}$. Ten tekst i obraz przybliżają ikonosferę, w której narodziła się omawiana metafora imitatio. Można w nim również zobaczyć obrazowy archetyp bardzo popularnego toposu nowożytnej ikonografii chrześcijańskiej, który realizuje się w znanych przedstawieniach ukazujących rozmowę Chrystusa dźwigającego krzyż z człowiekiem. $Z$ reguły nie jest to już anonim, ale postać konkretnego świętego lub świętej ${ }^{4}$.

Zagadnienie imitatio Christi wielokrotnie było przedmiotem dociekań badaczy, komentowano je także na gruncie sztuki chrześcijańskiej ${ }^{5}$. Postępowanie za Chrystusem i naśladowanie Go łączą się także z pojęciami compassio i conformitas. Towarzyszy temu wspaniała budująca literatura, tematyka ta rozkwitła zwłaszcza w nurcie devotio moderna. Należy tu oczywiście przywołać najpopularniejszy tekst Tomasza à Kempis O naśladowaniu Chrystusa ${ }^{6}$. Autor domaga się od swoich

Zob. Ch. Frugoni, F. Manzari, Immagini di san Francesco..., dz. cyt., s. 381.

Zob. Ch. Frugoni, F. Manzari, Immagini di san Francesco..., dz. cyt., s. 282.

4 Kontekst tej rozmowy najczęściej ma charakter wizji mistycznej, ukazuje spotkanie człowieka z Bogiem „twarzą w twarz” i jest rzeczywistym, bezpośrednim dotknięciem sacrum (vide popularna ikonografia św. Ignacego Loyoli, Jana od Krzyża, niektóre nowożytne przedstawienia Nawrócenia św. Pawła; sporadycznie ten temat obecny jest także w przedstawieniach wielu innych świętych).

Zob. np. uwagi wprowadzające w studium M. Walczak, „Alter Christus”. Studia nad obrazowaniem świętości w sztuce średniowiecznej na przykładzie św. Tomasza Becketa, Kraków 2001, s. 25-52 (Ars Vetus et Nova, t. 5).

6 Zob. [Tomasz à Kempis], Naśladowanie Chrystusa, tłum. S. Kuczkowski sJ, Kraków 1999, s. 116-124 (rozdz. 12: Królewska droga krzyża świętego). W rozlicznych wydaniach i tłumaczeniach tekstu pojawiają się także np. ryciny frontispisów, ilustrujące wywody autora w sposób dosłowny, ukazujące liczne grupy wiernych idące, upadające pod krzyżami, prowadzone przez Chrystusa (np. frontispis w paryskim wydaniu L'imitation de Jesus Christ z roku 1646), niekiedy łączone z motywem wąskiej bramy, przez którą wiedzie droga do królestwa niebieskiego (np. frontispis wydania kolońskiego z roku 1647 De imitatione Christi, tekst przygotował H. Rosweyde sı). Niewątpliwie popularność dzieła przekładała się także na popularność tych rycin jako wzorców ikonograficz- 
czytelników bezwzględnej wierności „królewskiej drodze krzyża”, ukazując jego splendor i moc, i nawołuje:

Weź więc swój krzyż i idź za Jezusem, a będziesz szedł drogą życia wiecznego. Przeszedł On przed tobą, niosąc dla siebie krzyż, byś i ty niósł swój krzyż i chciał umrzeć na krzyżu?

Jeśli chętnie niesiesz krzyż, będzie cię niósł i doprowadzi do upragnionego celu, gdzie mianowicie będzie koniec cierpienia, lecz sam cel nie będzie miał końca. Jeśli niechętnie niesiesz krzyż, sam sobie sprawiasz ciężar i siebie samego bardziej obciążasz, a jednak musisz go wytrzymać. Jeśli odrzucisz jeden krzyż, inny bez wątpienia znajdziesz i być może cięższy ${ }^{8}$.

Omawiana ikonografia okrzepła w odrębny typ ikonograficzny w czasach nowożytnych, ale ma średniowieczne precedensy. Są to pojedyncze przykłady, zwykle miniatur wyrastających z narracji biblijnej, ale poprzez swoją niejednoznaczność ikonograficzną mogące wskazywać na wolę twórcy do zilustrowania treści przesłania o postępowaniu za Chrystusem i dźwiganiu własnego krzyża9 Te najwcześniejsze przykłady nie wpisują się w kontekst ikonografii zakonnej. Dopiero w wieku xv pojawia się zróżnicowana produkcja artystyczna, którą jednoznacznie można uważać za początek nowego typu ikonografii chrześcijańskiej i dosłowną ilustrację przytoczonych na początku wersów ewangelicznych. Tak jak słowa Chrystusa są skierowane do wszystkich chrześcijan, tak też ikonografia ma charakter powszechny, nie ogranicza się jedynie do kręgu ikonografii zakonnej. Za Chrystusem może postępować każdy człowiek pobożny, ten egalitaryzm barokowa alegoryka zamknęła w obrazie owieczki dźwigającej własny krzyż, pokornie drepczącej za Zbawicielem i Jego krzyżem. Jednak to w kręgu ikonografii monastycznej powstają najciekawsze i najliczniejsze realizacje. Nie jest to zaskoczeniem, biorąc pod uwagę szczególny charyzmat życia zakonnego, które całe nakierowane jest na naśladowanie Jezusa, w którym każdy krok na ludzkiej drodze jest analizowany, medytowany, formatowany w duchu ideału „już nie ja żyję, ale żyje we mnie Chrystus”.

nych. Pozostają one jednak poza ścisłym kręgiem sztuki zakonnej, zwykle ukazują w tłumie idącym za Chrystusem przedstawicieli różnych stanów społecznych.

7 [Tomasz à Kempis], Naśladowanie Chrystusa, dz. cyt., s. 117.

8 [Tomasz à Kempis], Naśladowanie Chrystusa, dz. cyt., s. 119.

9 Przykłady realizacji podaje F. O. Büttner, Imitatio pietatis. Motive der christlichen Ikonographie als Modelle zur Verähnlichung, Berlin 1983, s. 56-62. 
Zauważyć należy, że już w Xv wieku omawiana alegoria pojawia się we w pełni rozwiniętym wariancie kompozycyjnym w kręgu ikonografii franciszkańskiej. Przykładem jest rysunek z rękopisu tzw. Franceschina, znajdującego się obecnie w Perugii (Biblioteca Augusta, ms 1238; Giacomo Oddi, 1474), prezentujący Chrystusa, który dźwigając krzyż, wskazuje jednocześnie dłonią drogę ${ }^{10}$. Grupie zakonników podążających za Nim przewodzi św. Franciszek z Asyżu. Zwrócony ku niemu Chrystus wydaje się zachęcać do wysiłku, zaś Franciszek poprzez wyjątkowy dar stygmatów jest idealnym pośrednikiem, za którym pójdą zakonni bracia. Być może to właśnie w kręgu franciszkańskim najwcześniej zaadaptowano omawianą ikonografię na potrzeby zakonne, a św. Franciszek był pierwszym zakonnikiem, którego można zidentyfikować jako konkretną osobę podążającą za Chrystusem także w indywidualnych przedstawieniach (np. drzeworyt na frontispisie dzieła Bartholomaeusa da Pisa De conformitate vitae beati Francisco ad vitam Domini wydanego w Mediolanie w roku 1513).

Równolegle oczywiście powstawały realizacje propagujące ideę imitatio Christi, także poza nurtem monastycznym, często bardzo ciekawe, łączące się z komentarzami literackimi, np. drzeworyt Hansa Baldunga Griena do dzieła Ulricha Pindera Der beschlossen Gart..., wydanego w Norymberdze w 1505 roku $^{11}$, czy ukazujące rys indywidualnej dewocji, jak rysunek piórkiem wykonany przez Albrechta Dürera w modlitewniku Lazarusa Spenglera (jako luźne karty w British Museum), gdzie na odrębnych kartach widzimy Chrystusa z krzyżem i podobnie dźwigającego krzyż patrycjusza ${ }^{12}$.

Analizując przekazy ikonograficzne powstające poza nurtem ikonografii zakonnej, baczniejszą uwagę w kontekście poruszanego tematu wypada zwrócić na serie graficzne ilustrujące modlitwę Pater noster. Wydają się one tym ikonograficznym impulsem, który znakomicie przyczynił się w XVI wieku do rozpropagowania modelu obrazowania imitatio Christi w omawianym tu typie. Interesująca jest dla nas ilustracja trzeciej prośby: Fiat voluntas tua sicut in coelo et in terra (Bądź wola Twoja, jako w niebie, tak i na ziemi). Akcentuje ona pokorę, oddanie, wyzbycie się egoistycznych dążeń, dlatego przy jej narracyjnym ilustrowaniu inspirowano się znanymi skądinąd tematami ikonografii chrześcijańskiej: Modlitwą w Ogrójcu,

10 Zob. F. O. Büttner, Imitatio pietatis..., dz. cyt., s. 58, il. 45. Opis manuskryptu pod adresem http://augusta.alchimedia.com/scheda.aspx?prov=div\&ID=122 (13.02.2016).

${ }_{11}$ Zob. Hans Baldung Grien. Das graphische Werk. Vollständiger Bildkatalog der Einzelholzschnitte, Buchillustrationen und Kupferstiche, bearb. M. Mende, Unterschneidheim 1978, poz. kat. 93.

${ }_{12}$ Oba rysunki zostały opatrzone inskrypcjami, u stóp Chrystusa umieszczono znane nam już pouczenie o ludziach, którzy nie biorąc krzyża, nie są godni Zbawiciela, zaś figurze Spenglera towarzyszy fragment Psalmu 22, 4. 
Drogą na Golgotę. Za Chrystusem niosącym krzyż podążały wielkie tłumy ludu, kobiet i mężczyzn różnych stanów, mozolnie dźwigające swoje krzyże, co znakomicie odzwierciedlało powszechny charakter modlitwy i równie powszechny charakter odkupienia (Chrystus umarł za wszystkich). Do najwcześniejszych przykładów realizacji Ojcze nasz, gdzie trzecią prośbę ilustruje tłumny pochód wiernych z krzyżami, któremu patronuje potężna półpostać Boga Ojca w obłokach, należy drzeworyt Monogramisty cv, wykonany według Hansa Holbeina Młodszego, datowany na 1524 rok (Bazylea, Kunstmuseum, Kupferstichkabinett) ${ }^{13}$. Podobny schemat kompozycyjny zastosował około 1530 roku Daniel Hopfer (Pinacoteca di Bologna, Cabinetto Disegni e Stampe) ${ }^{14}$. Także w malarstwie tablicowym odnajdujemy przykłady realizacji Pater noster w tej konwencji ${ }^{15}$. Ze względu na klasę artystyczną dzieła warto wspomnieć w tym wyliczeniu także późniejszą (druga połowa Xvi wieku) serię grafik według Maartena van Heemskercka wydaną przez Jana Wierixa (Wolfegg, Kunstsammlungen der Fürsten zu Waldburg-Wolfegg). W dość statyczny schemat artysta tchnął wiele energii, dramatycznie poruszając kompozycję, niemal manierystycznie aranżując całość (il. 2). Można uwierzyć, że dźwiganie krzyża to wielkie wyzwanie dla wiernych, któremu nie wszyscy podołają, o czym świadczą upadki, ekspresyjne gesty.

Analizując alegorie związane z życiem zakonnym, jako interesujący przykład należy wspomnieć znacznie późniejszą serię graficzną z przełomu Xvi i XvII wieku wykonaną przez Elie du Boisa (siedem rycin oraz towarzyszący im frontispis) ${ }^{16}$. Każda z próśb jest ukazana jako uskrzydlona personifikacja, której towarzyszy bardzo skomplikowany program ikonograficzny, łączący siedem sakramentów i cnót, sceny ewangeliczne oraz symbole z licznymi objaśniającymi tekstami. Trzecia prośba Modlitwy Pańskiej ukazana została w habicie zakonnym przepasanym sznurem, co kojarzy się z zakonnym strojem franciszkanów, choć tu może być jedynie dobitną oznaką ubóstwa i wyrzeczenia (il. 3) ${ }^{17}$. W tle umieszczono

${ }_{13}$ Zob. R. Mastacchi, Pater noster. La raffigurazione della Preghiera del Signore nelle stampe, Siena 2012, s. 69-71, il. 29.

${ }^{14}$ Zob. R. Mastacchi, Pater noster..., dz. cyt., s. 78-79, il. 34 .

15 Częściowo zachowany cykl Ojcze nasz (Chrystus nauczający apostołów modlitwy oraz ilustracje trzech pierwszych próśb), deska, po 1523 roku, Turyngia (?), Angermuseum, Erfurt. Zob. Alltag und Frömmigkeit am Vorabend der Reformation in Mitteldeutschland. Katalog zur Ausstellung „Umsonst ist der Tod”, Hrsg. H. Kühne, E. Bünz, Th. T. Müller, Petersberg 2013, s. 311n, poz. kat. 6.5.5 (autorzy hasła Vaterunser-Tafel (Fragment) P. Knüvener, H. Kühne).

16 Seria wydana w Paryżu przez Nicolasa de Mathoniera. Zob. R. Mastacchi, Pater noster..., dz. cyt., s. 52-53, il. 17 .

${ }_{17}$ Każda z personifikacji ma inny ubiór, to ważny atrybut ukazujący różne stany społeczne, nawiązujący jednoznacznie do treści prośby. 
dwie sceny pasyjne: Modlitwę w Ogrójcu ${ }^{18}$ oraz Drogę na Golgotę (Chrystusa niosącego krzyż), a pod stopami - ilustrację sakramentu kapłaństwa, cnotę Miłosierdzia wraz z symbolicznymi zwierzętami: pelikanem karmiącym krwią młode oraz kokoszką, pod skrzydłami której chronią się pisklęta. Inskrypcja w kartuszu objaśnia, że postać namalowana jest w habicie zakonnym symbolizującym ślub posłuszeństwa, przez który w zakonach wyrzekano się własnej woli, aby pełnić wolę Bożą. Koresponduje to $\mathrm{z}$ sakramentem kapłaństwa, ponieważ przepowiadanie pozwala poznać wolę Bożą, a jakże można by przepowiadać, nie będąc do tego powołanym. A zatem do poznania woli Bożej jest niezbędne powołanie sług i ich ordynacja ${ }^{19}$.

Alegoryczne przedstawienie „pójścia za Chrystusem” w ikonografii monastycznej rozpowszechniło się zarówno w formie tłumnych pochodów całych wspólnot zakonnych, jak i indywidualnej drogi doskonalenia pojedynczego człowieka, stąd dysponujemy przykładami dzieł skrajnie zróżnicowanymi. Jako realizacje typowe dla dwóch modeli prezentacji tematu można przywołać: miniaturę z Graduału karmelitańskiego (klasztor karmelitów na Piasku w Krakowie) oraz malowidło z klasztoru benedyktynek w Staniątkach. Pierwszy z nich ukazuje grupę karmelitów, a więc członków jednego zakonu, podążających za Chrystusem jako wspólnota $^{20}$. To silne podkreślenie ducha communio, tego, że idziemy razem, jesteśmy za siebie wzajem odpowiedzialni i postrzegani jako jedność. Każdy z członków wspólnoty ma własny krzyż, a więc własną drogę, ale decyduje się ją przejść ramię w ramię z innymi podobnymi grzesznikami. Ojciec Stanisław ze Stolca, malując Chrystusa, odszedł od konwencjonalnego ujęcia postaci. Jezus spod przytłaczającej go belki krzyża patrzy wprost na nas, widzów. Nie tylko karmelitańskiej wspólnocie, ale także nam próbuje wskazać drogę. To bezpośrednie zaproszenie, przynaglenie - weź swój krzyż, także ty, który jedynie patrzysz. Anonimowy

18 Już św. Cyprian w traktacie O modlitwie Pańskiej (III w.), przywołując słowa: „bądź wola Twoja", ilustruje je rozważaniami o Jezusie modlącym się w Ogrójcu.

19 Seria zyskała popularność, o czym świadczą naśladownictwa malarskie i graficzne, odznaczające się jednak uproszczeniem wątków ikonograficznych: w polichromii drewnianego kościoła w Binarowej zrezygnowano z inskrypcji objaśniających, cnót i scen ewangelicznych; w serii grafik wydanej przez Hermana Weyena pozostawiono wyłącznie personifikacje otoczone inskrypcjami, rezygnując z pozostałych wątków.

${ }_{20}$ Zob. T. Chrzanowski, T. Maciejewski, Graduat karmelitański z 1644 roku o. Stanisława ze Stolca, Warszawa 1976, s. 18-19, 41 (fol. 96). Por. także K. Moisan-Jabłońska, Obrazowanie walki dobra ze złem, Kraków 2002, s. 379. Autorka wskazała dodatkowy motyw ikonograficzny, obecny w miniaturze - puste kartki przybite do krzyża - który rozszerza krąg inspiracji ikonograficznych na przedstawienia Chrystusa-Baranka Bożego, który poniósł na krzyż nasze grzechy. Przedstawienie to stanowi odrębny typ ikonograficzny. 
obraz w Staniątkach (xviII wiek) prezentuje samotną siostrę w benedyktyńskim habicie, zapatrzoną w postać Zbawiciela, który odwraca ku niej głowę ${ }^{21}$. Wzajemną więź podkreślają nie tylko spojrzenia, które się spotykają, ale także dłoń mniszki położona na sercu. Tego rodzaju ikonografia podkreśla najbardziej intymną więź, którą pielęgnuje się w „izdebce swego serca”. Towarzyszy jej najgłębsza pokora i uniżenie (malarz sugeruje je poprzez namalowanie mniszki w perspektywie hierarchicznej). Ten afektywny aspekt malowidła zbliżał je do innych, podobnych w wymowie dzieł sztuki, które próbowały oddać duchowe bogactwo życia mniszek, towarzysząc im w postępach na drodze oczyszczenia i zjednoczenia.

Wskazane wyżej przykłady to rozwiązania typowe dla ikonografii nowożytnej. Na przeciwległych biegunach mieszczą się skrajności w obrazowaniu omawianej metafory. Na parapecie chóru w ponorbertańskim kościele Trójcy Świętej i NMP w Strzelnie wśród pięciu owalnych malowanych kartuszy, prezentujących alegoryczny wykład doskonałości zakonnej, znajduje się także wizerunek samotnej norbertanki dźwigającej wielki krzyż (pierwsza połowa XvıII wieku) ${ }^{22}$. Z obłoków wyłania się ku niej ręka z koroną. Całość objaśnia banderola z inskrypcją: Tolle crucem auferes coronam (il. 4). Ta quasi-emblematyczna konstrukcja to najbardziej lapidarny ikonograficzny zapis idei naśladowania Chrystusa dźwigającego krzyż. Z obrazu zniknął nawet Chrystus, zostało tylko palące wezwanie: „Weź krzyż!". I nagroda w postaci niebiańskiej korony chwały. Jest to zapis intymnej, mistycznej drogi poznania Boga, którą musi przejść każdy zakonnik i zakonnica całkowicie samotnie, aby w głębi duszy dotknąć sacrum. Idąc, przygnieciony ciężarem krzyża, człowiek często nie widzi Boga, zawsze jednak powinien wierzyć, że jest przed nim, że poprzedza go w bólu Golgoty. Ascetycznej wersji ikonografii przeciwstawia się niezwykle bogata, wielowątkowa opowieść ikonograficzna, zajmująca olbrzymią powierzchnię stropu tzw. Sali Opackiej w klasztorze pocysterskim w Lądzie nad Wartą, namalowana przez franciszkanina

${ }^{21}$ Zob. K. Moisan-Jabłońska, Obrazowanie walki..., dz. cyt., s. 379. Autorka cytuje inskrypcję widoczną na obrazie: „Kto chce iść za mną niech sam siebie zaprze a weźmie krzyż swoy, a Math. 26”.

${ }^{22} \mathrm{~W}$ czasie powstania malowideł na emporze muzycznej mieścił się chór zakonny, malowidła niejako prezentowały na zewnątrz wizerunek idealnej mniszki, skrytej za klauzurą przed ludzkim wzrokiem. Również pozostałe znajdujące się na balustradzie obrazy, w podobnym duchu emblematycznie konstruowanej wypowiedzi słowno-obrazowej, pouczają o tym, jakim wartościom ma hołdować w swoim życiu mniszka. Kościół i klasztor były w posiadaniu konwentu norbertanek do 1837 roku, obecnie jest to świątynia parafialna, co pozbawia pierwotny wystrój właściwej mu ikonosfery. 
Adama Swacha w $1722 \mathrm{roku}^{23}$. Dziesiątki postaci, wielowątkowa kompozycja, rozmaite personifikacje uatrakcyjniają przekaz, ale jego jądro sprowadza się do znanej już figury Chrystusa dźwigającego krzyż, na którym umieszczono cytat z Ewangelii Mateusza $(16,24)$, wzywający do pójścia za Jezusem. Cel tej drogi, tak skromnie w postaci korony wytyczony na wzmiankowanym powyżej obrazie ze Staniątek, tu został rozmalowany w całej okazałości jako Niebiańskie Jeruzalem, ponad którym unosi się symbolicznie Bóg Ojciec w otoczeniu czterech zwierząt apokaliptycznych. Za Chrystusem podąża kilkadziesiąt postaci kobiet i mężczyzn w zakonnych szatach. Ich różnorodność wskazuje, że celem artysty było namalowanie przedstawicieli wszystkich zgromadzeń zakonnych swojego czasu. Wymowę teologiczną dzieła pogłębiają inskrypcje na krzyżach niesionych przez ludzi, ich odczytanie złożyłoby się na imponujący wykład teologii Krzy$\dot{z}^{24}$. W głębi, aż po horyzont, ciągnie się las krzyży nadal oczekujących na tych, którzy wezmą je w dłonie. Wizerunek zawiera także autoportret Adama Swacha, który skromnie klęcząc przy krawędzi obrazu, podtrzymuje krzyż niesiony przez swojego duchowego ojca św. Franciszka, tym samym wpisując własny żywot zakonnego malarza w wielki nurt imitatio Christi. Drugą połowę malowidła zajmuje obraz grzesznej ludzkości, czyli złych uczynków popełnianych przez tych, którzy odrzucili krzyż. Czeka na nich ognista otchłań. Dzieło Swacha jest najwymowniejszą alegorią życia zakonnego, ponieważ pokazuje jego bogactwo; różne szkoły duchowości reprezentowane są np. przez obecnych w tłumie św. Benedykta, Bernarda z Clairvaux, Gwidona z Montpellier, Franciszka, Dominika, Ignacego Loyolę, Jana od Krzyża. Liczebność i różnorodność nie przeszkadzają

${ }^{23}$ Zob. K. Moisan-Jabłońska, Obrazowanie walki..., dz. cyt., s. 377-379, tu wcześniejsza literatura; reprodukcja malowidła w: J. Nowiński, Ląd nad Wartą, Warszawa 2009, s. 42-43. Por. także A. E. Czerwińska, Adama Swacha portret własny - czyli kilka uwag o sygnaturach i autoportretach barokowego artysty, [w:] Architektura znaczeń. Studia ofiarowane prof. Zbigniewowi Bani w 65. rocznice urodzin i w 40-lecie pracy dydaktycznej, red. A. S. Czyż, M. Wiraszka, Warszawa 2011, s. 424-439.

${ }^{24}$ Autor kierował malowidło do bardzo szczególnych, dziś napisalibyśmy - sprofilowanych odbiorców, ukształtowanych w szkole zakonnych studiów teologicznych, którzy tę ikonografię mogli traktować jako swoiste repetytorium wiedzy teologicznej. Czytając np.: „Signaculum Regium est crux”, „Passionibus Christi per patientiam participemus”, rozumieli głębię tych wersów. Dla kontrastu można przywołać obraz z Koła (1813 r.), gdzie Chrystusa otaczają krzyże (bez postaci) z inskrypcjami w rodzaju: „Przegrany proces”, „Nieszczęście w Handlach” czy „Zniewaga w oczach”. Dopiero w tym zestawieniu widać, co może czekać ikonografię, która zbyt blisko zetknie się z profanum. O obrazie zob. E. Kubiak, Krzyż jako droga do zbawienia - analiza obrazu $z$ klasztoru bernardynów w Kole „Chrystus niosący krzyż” na tle innych przedstawień z epoki, [w:] Sztuka nowożytna i nowoczesna, Łódź 2010, s. 27-48 (Studia Polski Środkowej, 4). 
w zgodnym dążeniu do wspólnego celu, bo „jeden jest Kościół” i jedna droga - Chrystus (J 14, 6). Przeciwstawione są mu różne występki dokonywane „W świecie”, czego najdobitniejszym podkreśleniem jest personifikacja Pani Świat umieszczona na pierwszym planie "grzesznej strony malowidła”. Świat kusi i jest pełen pułapek, życie konsekrowane wydaje się więc wybawieniem, wybraniem dobrej, choć obarczonej ciężarem krzyża, drogi. Malowidło lądzkie to wielka apologia życia zakonnego jako podążania za Chrystusem do niebieskiego Jeruzalem drogami wyznaczonymi przez różne reguły zakonne.

Jako swoiste podsumowanie tego krótkiego przeglądu alegorycznych wizerunków, obrazujących naśladowanie i postępowanie za Chrystusem, może posłużyć rycina wydana przez Jeana Messagera, zatytułowana Manus Religiosorum Typus (il. 5). Tytułowa manus, czyli ręka, to znany już od wieków schemat „duchowej dłoni” jako mnemotechnicznej pomocy w nauczaniu wiary ${ }^{25}$. Przywołana rycina ukazuje dłoń z umieszczonymi na każdym palcu postaciami Chrystusa, zakonników, Boga Ojca, opatrzonymi inskrypcjami: Ad quid venisti?, Quid ad te?, Est mea culpa, Libenter, Deo gratias. W centrum dłoni umieszczono figurę św. Franciszka z cytatem z Psalmu 119 (118), 109: „Moje życie jest w ciągłym niebezpieczeństwie [lecz prawa Twojego nie zapominam]”. Całość zaopatrzono w podpis będący cytatem z Sentencji Piotra Lombarda, w którym autor zadaje fundamentalne pytanie - dlaczego zostało nałożone na człowieka wymaganie doskonałości, gdy wiadomo, że jej nie posiada? Mnich niosący za Chrystusem swój krzyż został umieszczony na tle kciuka, pod banderolą Ad quid venisti. Przesłanie tej alegorii byłoby niejednoznaczne, gdyby nie obszerna publikacja autorstwa Hermanna Motta, Manus Religiosorum. Olim Formata, Nvnc per Verbum Dei..., która stanowi jej doskonałe objaśnienie ${ }^{26}$. Książkę „wydano drukiem u Braci Mniejszych” i „ofiarowano nowicjuszom św. Franciszka”, stąd uprzywilejowane miejsce tego świętego w grafice. Jest przeznaczona, jak kwiecisty barokowy tytuł wskazuje, do nauki doskonałego, pobożnego i uczciwego życia, w oparciu o Słowo Boże, Tradycję i mistrzów życia duchowego. I tak właśnie, jak na podręcznikowy wy-

${ }^{25}$ Koncept dłoni nie jest nowy, stosowano go na przykład w ilustrowaniu tak popularnych dzieł jak Ćwiczenia duchowne św. Ignacego Loyoli. O kształtowaniu się alegorii oraz jej zastosowaniach w przekazie treści wiary i pomocy w obrazowym nauczaniu zob. W. Brückner, Bildkatechese und Seelentraining. Geistliche Hände in der religiösen Unterweisungspraxis seit dem Spätmittelalter, „Anzeiger des Germanischen Nationalmuseums Nürnberg” (1978), s. 35-70.

${ }^{26}$ Korzystam z wydania: H. Mott, Manus Religiosorum. Olim Formata, Nvnc per Verbum Dei, \& santa Sanctorum Patrum, ac magnorum vitae spiritualis Magistrorum documenta, de vita cum honeste \& religiose..., Colonie 1669 . O popularności głoszonych nauk świadczy fakt, że tekst łaciński przetłumaczono na niemiecki i wydano jeszcze kilkadziesiąt lat później (Regensburg 1742). 
kład, należy na nią patrzeć. Aby być skuteczniejszym, Hermann Mott posłużył się mnemotechnicznym zabiegiem: dłoń jest tu rozumiana bardzo dosłownie jako pomoc w wykładzie treści. Tekst książki poprzedza swoisty frontispis $\mathrm{z}$ wizerunkiem dłoni, który zaopatrzono w liczne inskrypcje (nie ma tam przedstawień obrazowych), są także zapisy na banderolach ponad palcami, analogiczne jak w omawianej wyżej grafice ${ }^{27}$. Teksty te są tytułami poszczególnych rozdziałów i podrozdziałów, stanowią więc nic innego, jak spis treści, opisanie „na dłoni” zawartości książki. Na kciuku napisano czterowiersz, umieszczony także w tekście zasadniczym książki: Non velle meum facere [J 6, 38]; sed passiones vincere [Kol 3]; Sanctamque Crucem tollere [Mt 16]; Et Indie proficere [Ps 83]. Umieszczone w nawiasach odsyłacze do ksiąg biblijnych zapisano na marginesie ${ }^{28}$. Oto Chrystus dźwigający krzyż jest tym, który zstępuje z nieba, aby pełnić wolę Ojca, nie swoją. Daje nam przykład doskonałego posłuszeństwa i pokory: „bądź wola Twoja" - powtarza w Ogrójcu. Uczeń wobec takiego Nauczyciela musi odrzucić dawnego człowieka z jego uczynkami i „przyoblec nowego, który wciąż się odnawia ku głębszemu poznaniu Boga, według obrazu tego, który go stworzył”.

Wyczerpujące omówienie każdego z tych wersów następuje na dalszych kartach książki ${ }^{29}$. Mott cytuje słowa Tomasza à Kempis o tym, że Jezus ma wielu miłośników królestwa niebieskiego, lecz nader mało tych, którzy chcieliby dźwigać Jego krzyż, niewielu chciałoby cierpieć razem z nim. Autor pokazuje wszystkie niepowtarzalne walory krzyża, jego moc, chwałę. Namawia, przestrzega, zachęca, ponieważ nowicjusz musi wiedzieć, po co przyszedł do klasztoru, z kim idzie i w jakim kierunku podąża. Wykład Motta stanowi kwintesencję barokowej nauki o naśladowaniu Chrystusa w zakonnym życiu, można go czytać jako komentarz do każdego z obrazów prezentujących zakonników niosących swoje krzyże.

\section{Bibliografia}

Alltag und Frömmigkeit am Vorabend der Reformation in Mitteldeutschland. Katalog zur Ausstellung „Umsonst ist der Tod”, Hrsg. H. Kühne, E. Bünz, Th. T. Müller, Petersberg 2013.

${ }^{27}$ Rycina zaopatrzona jest w sygnaturę: Colonie Sumptibus Wilhelmi Friessem Bibliop. A: 1670.

${ }_{28}$ Zob. H. Mott, Manus Religiosorum..., dz. cyt., s. B2 [3] (książka ma paginację podwójną i niekonsekwentną).

29 Szczegółowa analiza wersu Sanctamque crucem tollere zob. H. Mott, Manus Religiosorum..., dz. cyt., s. 101-111. 
Brückner W., Bildkatechese und Seelentraining. Geistliche Hände in der religiösen Unterweisungspraxis seit dem Spätmittelalter, „Anzeiger des Germanischen Nationalmuseums Nürnberg" (1978), s. 35-70.

Büttner F. O., Imitatio pietatis. Motive der christlichen Ikonographie als Modelle zur Verähnlichung, Berlin 1983.

Chrzanowski T., Maciejewski T., Graduał karmelitański z 1644 roku o. Stanisława ze Stolca, Warszawa 1976.

Czerwińska A. E., Adama Swacha portret własny - czyli kilka uwag o sygnaturach i autoportretach barokowego artysty, [w:] Architektura znaczeń. Studia ofiarowane prof. Zbigniewowi Bani w 65. rocznicę urodzin i w 40-lecie pracy dydaktycznej, red. A. S. Czyż, M. Wiraszka, Warszawa 2011, s. 424-439.

Frugoni Ch., Manzari F., Immagini di san Francesco in uno Speculum humanae salvationis del Trecento, Padova 2006.

Hans Baldung Grien. Das graphische Werk. Vollständiger Bildkatalog der Einzelholzschnitte, Buchillustrationen und Kupferstiche, bearb. M. Mende, Unterschneidheim 1978.

Kempis T., Naśladowanie Chrystusa, tłum. S. Kuczkowski sృ, Kraków 1999.

Kubiak E., Krzyż jako droga do zbawienia - analiza obrazu z klasztoru bernardynów w Kole "Chrystus niosacy krzyż” na tle innych przedstawień z epoki, [w:] Sztuka nowożytna i nowoczesna, Łódź 2010, s. 27-48 (Studia Polski Środkowej, 4).

Mastacchi R., Pater noster. La raffigurazione della Preghiera del Signore nelle stampe, Siena 2012.

Moisan-Jabłońska K., Obrazowanie walki dobra ze złem, Kraków 2002.

Nowiński J., Ląd nad Wartą, Warszawa 2009.

Walczak M., „Alter Christus”. Studia nad obrazowaniem świętości w sztuce średniowiecznej na przykładzie św. Tomasza Becketa, Kraków 2001 (Ars Vetus et Nova, t. 5).

\section{Abstrakt}

Artykuł jest przyczynkiem do badań nad ideą naśladowania Chrystusa, wyrażoną w ikonografii chrześcijańskiej za pomocą obrazowej metafory dźwigania krzyża wespół z Chrystusem. „Kto nie bierze swojego krzyża, a idzie za mną, nie jest mnie godzien” (Mt 10, 38) - z mocą nauczał Chrystus. „Kto chce pójść za mną, niech się zaprze samego 
siebie, niech weźmie swój krzyż i niech mnie naśladuje" (Mk 8, 34, par. Mt 16, 24). Wierni temu przesłaniu komentatorzy tekstów biblijnych, egzegeci, teologowie i mistycy przez kolejne wieki rozwijali, pogłębiali, komentowali i objaśniali ideę naśladowania Chrystusa, posługując się chętnie także biblijną metaforą „wzięcia krzyża na swoje ramiona”.

\title{
Słowa kluczowe
}

krzyż, Jezus Chrystus, alegoria, życie zakonne, męka Pańska

\begin{abstract}
„Take up thy cross and follow Jesus...” The image of a man bearing a cross as an allegory of monastic life
\end{abstract}

The article is a monograph on the idea of following Christ, expressed in Christian iconography through the metaphor of bearing the cross together with Christ. "Whoever does not take up their cross and follow me is not worthy of me" (Matthew 10:38) was Christ's powerful message.

„Whoever wants to be my disciple must deny themselves and take up their cross and follow me" (Mark 8:34, par. in Matthew 16:24). Abiding by those words, Commentators of Biblical texts, experts on exegesis, theologians and mystics for centuries have developed, elaborated and explicated on the idea of following Christ, readily using the Biblical metaphor of „taking the cross upon one's arms”.

\section{Keywords}

cross, Jesus Christ, allegory, monastic life, the Passion of the Christ 


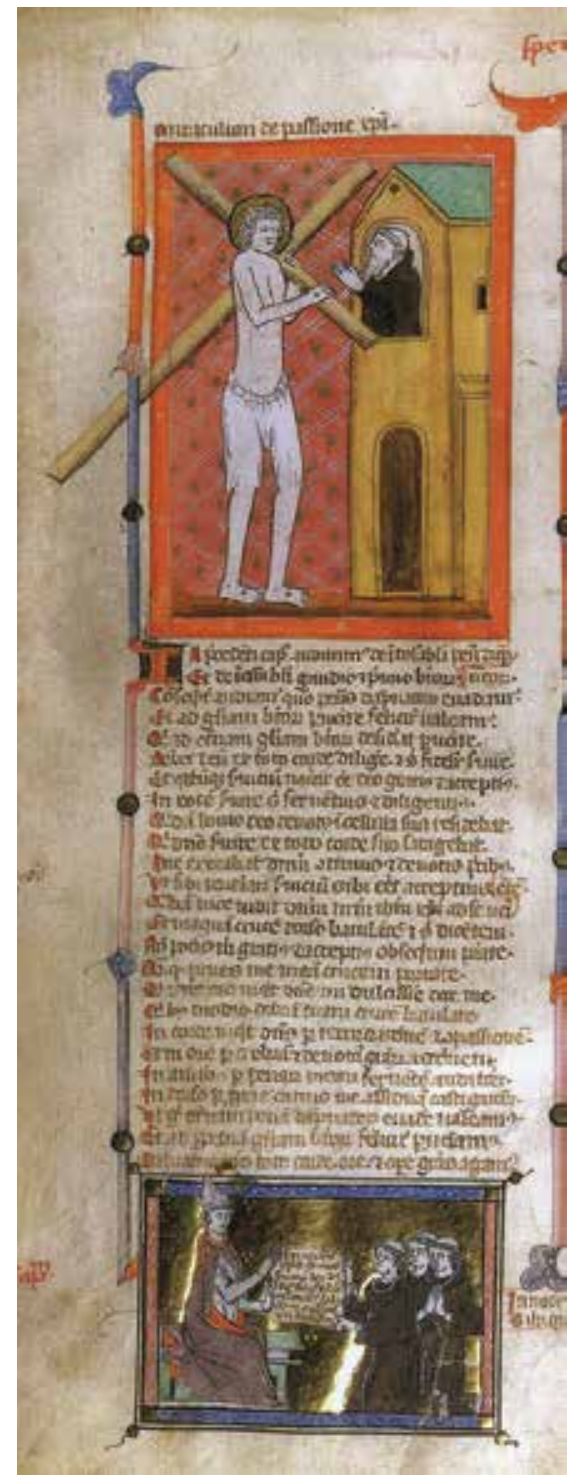

1. Chrystus rozmawiający z człowiekiem, miniatura, Speculum humanae salvationis, 1. poł. xiv w., Rzym, Biblioteca dell'Accademia Nazionale dei Lincei e Corsiniana. Repr. za: Ch. Frugoni, F. Manzari, Immagini di san Francesco in uno Speculum humanae salvationis del Trecento, Padova 2006, s. 282 


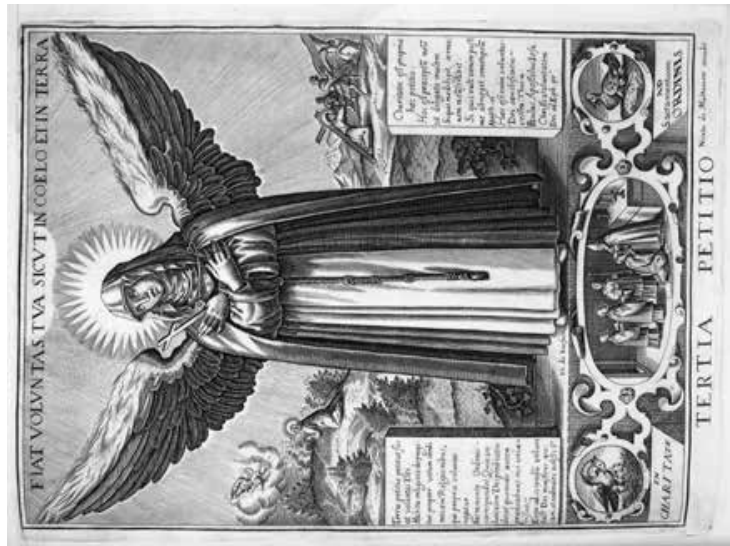

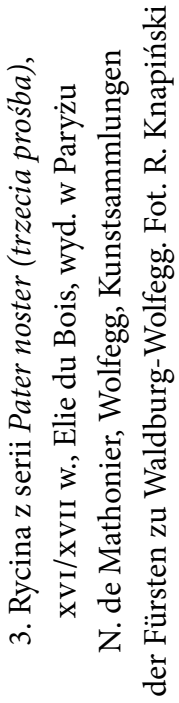
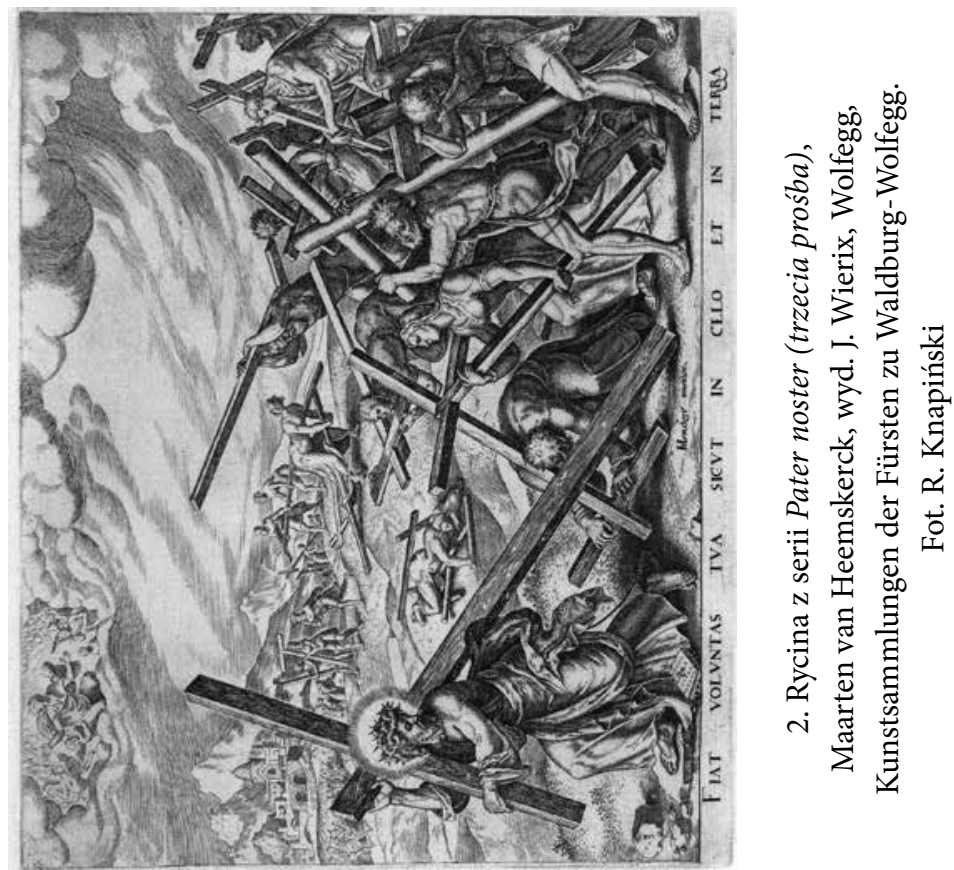


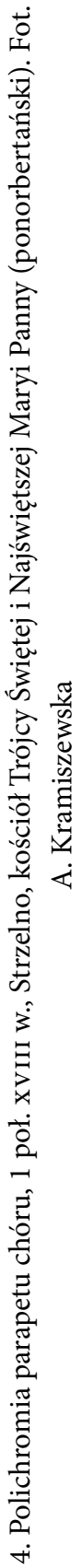




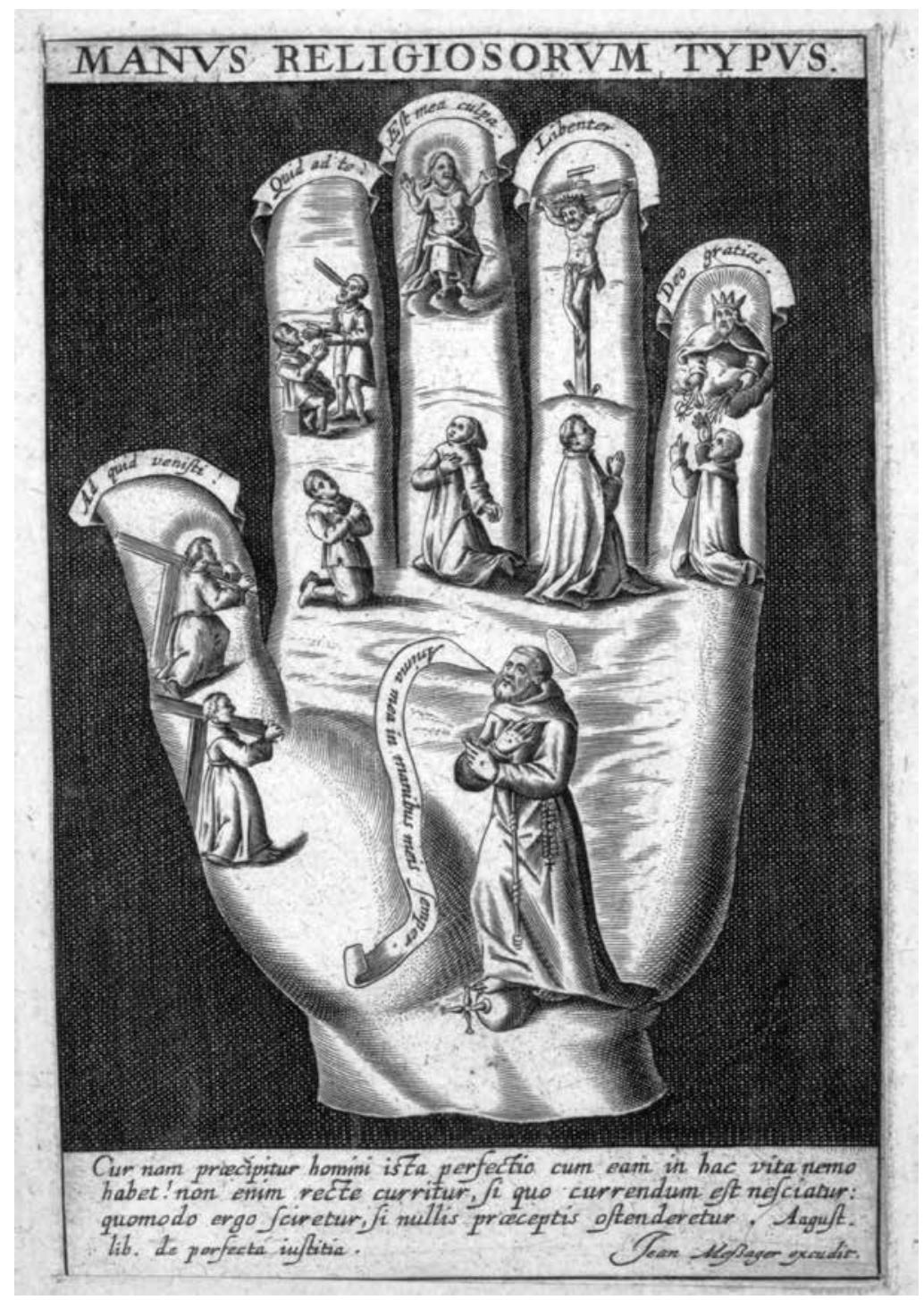

5. Rycina Manus Religiosorum Typus, Jean Messager, Wolfegg, Kunstsammlungen der Fürsten zu Waldburg-Wolfegg. Fot. R. Knapiński 